\title{
ANALYSIS OF FOOTWEAR BUSINESS DEVELOPMENT STRATEGY USING QSPM
}

\author{
AND SWOT ANALYSIS \\ Syufriadi IBRAHIM ${ }^{1 *}$, Dodik Ridho NURROCHMAT², Agus MAULANA ${ }^{1}$ \\ ${ }^{1}$ Management and Business, School of Business, IPB University, 16151, Indonesia \\ ${ }^{2}$ Department of Forest Management, Faculty of Forestry, IPB University Bogor, 16680, Indonesia
}

Received: 27.07.2019

Accepted: 06.11.2019

https://doi.org/10.24264/Ifj.19.4.1

\begin{abstract}
ANALYSIS OF FOOTWEAR BUSINESS DEVELOPMENT STRATEGY USING QSPM AND SWOT ANALYSIS
ABSTRACT. The main objective of this research is to analyze the strategy of developing the footwear business. Case studies were carried out at CV Hikmah Shoes Bogor. The initial analysis was carried out by identifying the business of the ongoing CV Hikmah shoe model and analyzing the external and internal scope to identify problems that occurred in the company. The descriptive method used to identify CV Hikmah Shoes Bogor using, Internal Factor Matrix (IFE) and External Factor Evaluation (EFE) used to analyze internal and external factors at CV Hikmah Shoes Bogor. SWOT matrix selected to determine the strategy to be implemented and Quantitative Strategy Planning Matrix (QSPM) is used as a process to determine strategic priorities for the company. The results of the SWOT Matrix in this study produced six alternative strategies which were chosen as development strategies at CV Hikmah Shoes Bogor. The best strategy is taken in developing the footwear business strategy, maximizing promotion and marketing using social media or e-commerce and continuing with the improvement business
\end{abstract} KEY WORDS: IFE, EFE, QSPM, SWOT Matrix

ANALIZA STRATEGIEI DE DEZVOLTARE A AFACERILOR ÎN DOMENIUL ÎNCĂLTĂMINTEI FOLOSIND ANALIZA QSPM ŞI SWOT

REZUMAT. Obiectivul principal al acestei cercetări este de a analiza strategia de dezvoltare a afacerilor în domeniul încălţămintei. S-au efectuat studii de caz asupra companiei CV Hikmah Shoes Bogor. Analiza iniţială a fost efectuată prin identificarea strategiei de afaceri actuale asupra modelelor de încălţăminte CV Hikmah şi prin analizarea cadrului intern şi extern pentru a identifica problemele apărute în cadrul companiei. Pentru a identifica strategia companiei CV Hikmah Shoes Bogor s-a utilizat metoda descriptivă prin evaluarea factorilor interni (IFE) şi evaluarea factorilor externi (EFE) în vederea analizării acestor factori în cadrul companiei. S-a selectat analiza SWOT pentru a determina strategia care urmează să fie pusă în aplicare şi s-a utilizat matricea planificării strategice cantitative (QSPM) ca proces de determinare a priorităţilor strategice pentru companie. Rezultatele analizei SWOT din acest studiu au generat şase strategii alternative selectate ca strategii de dezvoltare a companiei CV Hikmah Shoes Bogor. S-a ales cea mai bună metodă pentru elaborarea strategiei de afaceri în domeniul încălţămintei, maximizarea promovării şi marketingului prin utilizarea reţelelor sociale sau a comerţului electronic şi continuarea îmbunătăţirii afacerii.

CUVINTE CHEIE: IFE, EFE, QSPM, analiza SWOT

\section{ANALYSE DE LA STRATEGIE DE DEVELOPPEMENT DES AFFAIRES DANS LE SECTEUR DE LA CHAUSSURE UTILISANT L'ANALYSE QSPM ET} SWOT

RÉSUMÉ. L'objectif principal de cette recherche est d'analyser la stratégie de développement des affaires dans le secteur de la chaussure. Des études de cas ont été réalisées chez l'entreprise CV Hikmah Shoes Bogor. L'analyse initiale a été réalisée en identifiant la stratégie d'affaires en cours pour les modèles chaussure de CV Hikmah et en analysant la portée externe et interne pour identifier les problèmes survenus dans l'entreprise. Pour identifier la stratégie de l'entreprise CV Hikmah Shoes Bogor on a utilisé la méthode descriptive en évaluant les facteurs internes (IFE) et les facteurs externes (EFE) afin d'analyser ces facteurs au sein de l'entreprise. L'analyse SWOT a été choisie pour déterminer la stratégie à mettre en œuvre, tandis que la matrice de planification stratégique quantitative (QSPM) a été utilisée comme processus de détermination des priorités stratégiques de l'entreprise. Les résultats de l'analyse SWOT de cette étude ont généré six stratégies alternatives retenues comme stratégies de développement de l'entreprise CV Hikmah Shoes Bogor. La meilleure méthode a été choisie pour développer la stratégie commerciale de la chaussure, maximiser la promotion et le marketing grâce à l'utilisation de réseaux sociaux ou de commerce électronique et continuer à améliorer l'entreprise.

MOTS CLÉS : IFE, EFE, QSPM, analyse SWOT

\footnotetext{
* Correspondence to: Syufriadi IBRAHIM, Management and Business, School of Business, IPB University, 16151, Indonesia, email: adiebaim@ gmail.com
} 


\section{INTRODUCTION}

Manufacturing industries that focus on labour or non-oil and gas densities from 20112015 experienced an average growth of $6.1 \%$ per year and almost $60 \%$ of the output of this industrial sector was dominated by labourintensive industries which included the footwear industry, TPT industry (Textiles and Textile Products) and metal processing machines [1]. The manufacturing industry for processing genuine and imitation leather into footwear is an industry that is usually done both on a small scale industry or household and industry on a large scale. The existence of these small footwear industries plays an important role in the acquisition of foreign exchange and strengthens the national industrial structure [2], especially through the utilization and development of natural resource potential (SDA) owned by Indonesia and is one of the mainstay of sources of income and foreign exchange revenues originating from the non-oil and gas sector. Indonesian footwear exports in 2015 reached $\$ 4.7$ billion in footwear and have experienced significant development [3].

The Indonesian footwear industry has fulfilled $3 \%$ of the world's footwear needs. Indonesia has a high quality supply of Javanese cowhide which increases the attractiveness of the Indonesian footwear industry. The main markets for Indonesian exports are America, Europe and Japan. There are two types of manufacture of various footwear or shoes in Indonesia, the first through factories or industries, second through small and medium industries. The most dominant commodity of Indonesian or domestic original shoe making is through the Small and Medium Industries [4].

The small and medium industry sector is believed to be a sector that can lead other sectors in an economy towards progress because it has a high absorption capacity of labor to $\mathbf{5 7 . 9}$ million people in various regions in Indonesia. The small and medium industry sector according to its type there are two forms, manufacturing industry and service industry. The manufacturing industry which includes the processing industry, in its journey this industry has demonstrated its ability to absorb high labor reaching $\mathbf{1 5 . 7 3}$ million people in 2013 , or approximately $13.87 \%$ of Indonesia's workforce and ranked the 4th largest after agriculture, trade, and services [5].

Bogor Regency is one of the regencies in West Java Province which has a small and medium industry. One of the most prominent is the footwear processing industry compared to other processing industries with a total gross domestic income of Rp 100.528 billion in 2016 and an average growth of around 9 to $10 \%$ from 2011-2016 [1]. Ranked first in its contribution to GDP with a footwear processing business, one of the main businesses in Bogor Regency. The business in the field of footwear is one business that has a high level of competition. This requires producers to increase creativity which will produce their own ideas and uniqueness so that it can be an attraction to customers. A company that can produce a creative business needs the right strategy to produce excellence and be able to face the current and future business challenges. One of the business actors who tried to capture this opportunity was CV Hikmah Shoes, which is a company engaged in the field of footwear located in the city of Bogor, West Java.

The management of CV Hikmah Shoes plans to increase the company's revenue, but the company realizes that to support the current business growth, the right steps and strategies are needed in order to increase revenue well. Increasing the company's revenue source becomes a promising business prospect and becomes a consideration for prospective investors in CV Hikmah Shoes.

The plan desired by the management of CV Hikmah Shoes is also not easy to implement, management realizes that it still has some obstacles in business development, not finding the right solution in opening new markets 
for its business products which have been dependent on supplying certain brands, as well as competitive conditions companies in the business environment, not only in the products produced, variations in creative and innovative value added from each competitor must also be balanced in order to win the market [6].

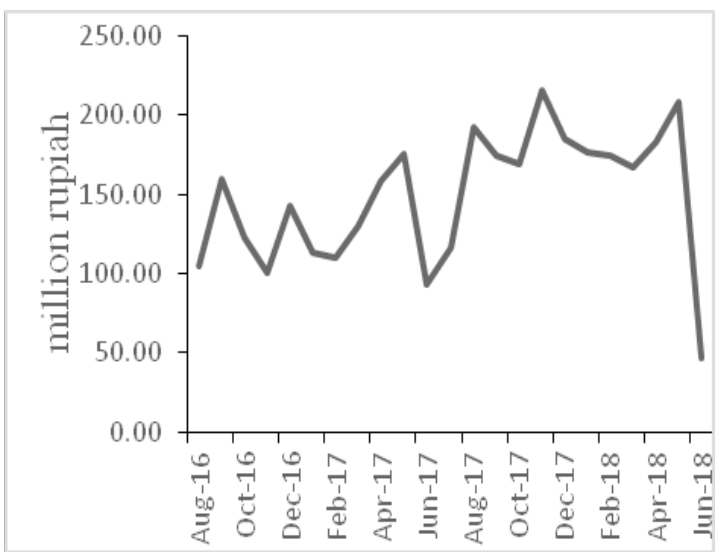

Figure 1. CV Hikmah Shoes total income for 2016-2018 (in millions of rupiah)

This can be seen from Figure 1 which shows the revenue of sales (revenue) of CV Hikmah Shoes for two years, from 2016 to 2018, during which period the company's income fluctuated which has not produced optimal performance. The company strives to achieve a monthly sales target of two hundred and fifty million a month but based on the revenue obtained from that period does not reach the expected target, there is even a decrease in income and a sharp decline in income after May 2018 directly affect the company's income. Business development CV Hikmah aims to get an overview and identification of current business, formulate strategies for product business development to achieve the company's revenue targets at CV Hikmah Shoes.

Giesen et al. [7] explain that business innovation is very important in achieving success in the present and future. When environmental conditions change rapidly and are so complex, company leaders need to understand when to adapt to business models and how to implement changes. Amit and Zott [8] emphasize that business innovation can provide significant opportunities both during the period of rapid economic growth and during times of turmoil.

\section{METHODS}

This research was conducted at CV Hikmah Shoes which began in October 2018-January 2019 in the village of Ciomas Harapan RT 01 RW 02 No 5 City of Bogor, West Java. This study used two types of data, primary data and secondary data. Primary data is obtained from in-depth interviews and filling in expert questionnaires by internal parties, the Manager, Production Section, Controlling Section, Management Section, External Reseller Design Section (PT Lastibani), Reseller (PT Bangjoan), Expert. Secondary data is obtained from documents owned by the company and literature studies.

\section{Data Analysis and Processing Method}

Data processing and analysis of this study uses the Environmental analysis aiming to identify strategic factors that will determine the company's future. Environmental analysis monitors, evaluates and disseminates information from the internal and external environment to the main person in the company [9]. Environmental analysis is divided into two, external and internal. Based on the level of influence on the company, the business environment or company environment can be divided into two categories, Internal Environment and External Environment [10]. By conducting environmental analysis companies or organizations will simultaneously be able to identify each critical threat, as well as its opportunities in a competitive environment [11]. The environmental analysis for the company can be used to measure how far competition in the environment has developed and its implications from evolution for opportunities and threats.

Through this mapping technique an overall description of the business processes 
carried out by the company will be obtained. The process of knowing the strategies that can be done to find out strategies for the company, used the SWOT Analysis method. According to David [12] SWOT Matrix (Strengths Weakness Opportunities Threats) is the right tool to help managers build four types of strategies, so (Strengths Opportunities), WO (Weakness Opportunities), ST strategies (Threats Strengths) and WT strategies (Weakness Threats) [13]. Furthermore, quantitative data from and SWOT Analysis are processed to compile and map strategies. At the stage of decision making the tool used is QSPM.

\section{Quantitative Strategic Planning Matrix}

Quantitative Strategic Planning Matrix (QSPM) is analytical tool used to decide on strategies to be used based on the attractiveness of alternative strategies that exist and to help assess alternative strategies objectively. QSPM is a tool used in the stages of decision making strategy and factors used in QSPM using factors that have been determined in the input stage, determining external factors and internal factors. Calculation of QSPM is based on input from the weight of the IFE and EFE matrix, as well as the alternative strategy at the matching stage [12]. The literature review provides a rationale for compiling a research framework on the influence of organizational justice in performance appraisal on satisfaction assessment and performance.

\section{RESULTS AND DISCUSSIONS}

\section{Internal Factor Analysis}

Internal factor analysis aims to identify the strengths and weaknesses in company. Strength is something that is owned by a company that is different from other companies and can support the company's activities. Weakness is the limitations or deficiencies in resources, skills and capabilities that seriously hinder the company's effective performance in the internal organization. As a result, organizational activities have not been carried out optimally [12]. The strengths and weaknesses in CV Hikmah shoes are shown in Table 1 IFE.

Table 1: IFE

\begin{tabular}{|c|c|c|c|}
\hline Internal Factor & Weight & Rating & $\begin{array}{c}\text { Score } \\
\text { Weight }\end{array}$ \\
\hline \multicolumn{4}{|l|}{ Power } \\
\hline 1. Variable footwear model and design & 0,09 & 4 & 0,36 \\
\hline 2. Experienced producing quality shoes & 0,11 & 4 & 0,44 \\
\hline 3. Product images that are already known & 0,10 & 4 & 0,40 \\
\hline 4. Availability of raw materials & 0,09 & 3 & 0,27 \\
\hline 5. CV Hikmah Shoes has a skilled and experienced workforce & 0,08 & 4 & 0,32 \\
\hline Sub total & & & 1,79 \\
\hline \multicolumn{4}{|l|}{ Weakness } \\
\hline 1. The marketing and promotion system that has not been maximal & 0,12 & 1 & 0,12 \\
\hline 2. Employee skill quality is still low in using technology & 0,11 & 2 & 0,22 \\
\hline 3. The production system is still based on orders & 0,09 & 2 & 0,18 \\
\hline 4. The selling price is still determined based on the wholesale price & 0,10 & 2 & 0,20 \\
\hline 5. The financial condition of the CV Hikmah shoes is limited & 0,11 & 1 & 0,11 \\
\hline Sub total & & & 0,83 \\
\hline Total & 1 & & 2,62 \\
\hline
\end{tabular}


The results of table 1 provide information about the strengths and weaknesses in CV Hikmah Shoes, sub-total strength has a weighting score of (1.79) with experienced variables producing quality shoes having the highest score (0.44). The highest weakness factor for weighting scores, the selling price is still determined based on the wholesale price $(0.20)$ and sub-total $(0.83)$. Scores of weights are obtained after multiplying the weights and ratings with the total weighted score with total accumulation of the variable strength and weakness of (2.62).

\section{External Factor Analysis}

The analysis of the external environment seeks to sort out the global problems facing the company in the form, function and interrelationship between the sections. For strategic development, this analysis is needed not only limited to the detailed analysis of opportunities and threats, but also to determine where and for what results of the analysis are used [12].

Opportunities are an important profitable situation in a corporate environment, which needs to be utilized by companies in developing business.

Table 2: EFE

\begin{tabular}{|c|c|c|c|c|}
\hline \multirow[t]{2}{*}{ NO } & External Factor & Weight & Rating & $\begin{array}{l}\text { Score } \\
\text { Weight }\end{array}$ \\
\hline & Opportunity & & & \\
\hline \multirow{2}{*}{\multicolumn{2}{|c|}{$\begin{array}{l}\text { 1. Increasing footwear export market in the world changes in style and lifestyle } \\
\text { konsumen }\end{array}$}} & 0,11 & 4 & 0,44 \\
\hline & & 0,08 & 3 & 0,24 \\
\hline & Progress in online business technology market in Indonesia & 0,11 & 4 & 0,44 \\
\hline 3. & The large population in Indonesia is ranked Fourth in the world & 0,11 & 4 & 0,44 \\
\hline \multicolumn{2}{|c|}{ Sub total } & & & 1,56 \\
\hline & Threat & & & \\
\hline & Increasing imports of similar footwear products & 0,13 & 1 & 0,13 \\
\hline & High level of competition in footwear production & 0,11 & 1 & 0,11 \\
\hline & Fluctuations in raw material prices & 0,12 & 2 & 0,24 \\
\hline 4. & Unstable economic conditions Indonesia and world & 0,12 & 2 & 0,24 \\
\hline & $\begin{array}{l}\text { The Indonesian government policy less supportive of the development of the } \\
\text { footwear industry }\end{array}$ & 0,11 & 2 & 0,22 \\
\hline \multicolumn{2}{|c|}{ Sub total } & & & 0,97 \\
\hline \multicolumn{2}{|c|}{ Total } & 1 & & 2,53 \\
\hline
\end{tabular}

Threat is a danger that usually occurs due to unfavorable developments, which will have impacts such as reduced profits and sales if no action is taken to survive. External factor aims to identify opportunities and threats that must be faced by the company (Table $2 \mathrm{EFE}$ ).

Based on the results of table $2 \mathrm{EFE}$, sub total opportunities is (1.56). The progress of online business technology gets the highest score with weight (0.44). Fluctuations in raw material prices and less stable economic conditions have the highest weighting score (0.24) and total weighted scoring opportunities and external factor threats are (2.53).

\section{SWOT Diagram}

Based on the calculation of Internal and External Factor analysis on CV Hikmah shoes, it can be illustrated in the SWOT diagram of Table 3 .

Table 3: Matrix SWOT

\begin{tabular}{llll}
\hline IFAS & & EFAS \\
CATEGORY & TOTAL & CATEGORY T & TOTAL \\
STRENGTH (S) & 1,79 & OPPORTUNITY (O) & 1,56 \\
WEAKNESS (W) & 0,83 & THREAT (T) & 0,97 \\
TOTAL (S-W) & 0,96 & TOTAL (S-T) & 0,59 \\
\hline
\end{tabular}


The results of the IFAS and EFAS matrix found that IFAS's final score was 0,96 and the total EFAS final score was 0,59. These results are then shown through the SWOT matrix.

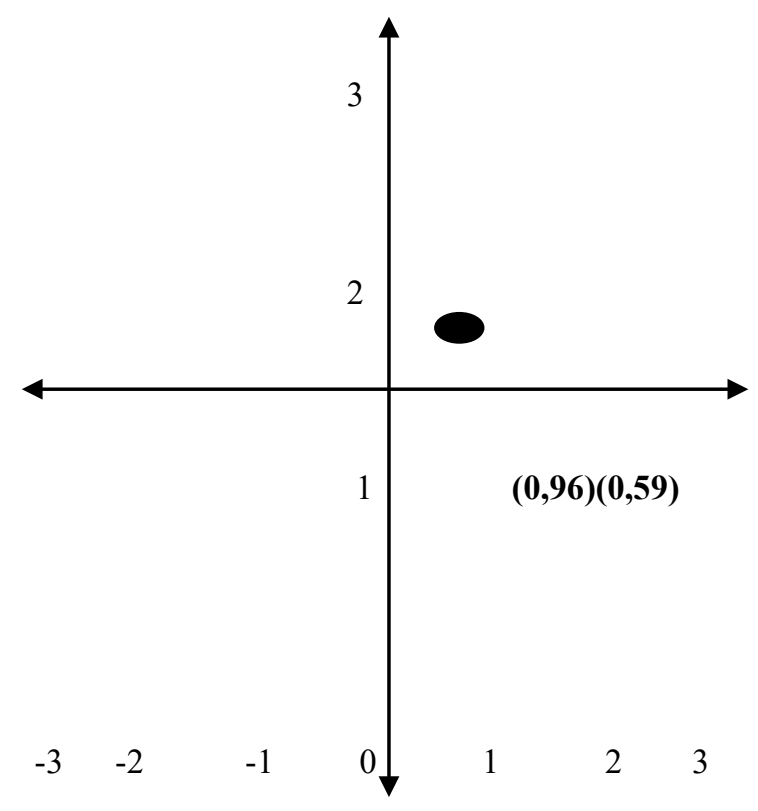

Figure 2. SWOT Diagram

Based on the SWOT diagram analysis, the position of CV Hikmah Shoes, in quadrant I, where in this position it is a condition that is very profitable for the company. The company can take advantage of existing opportunities
[14]. CV Hikmah shoes must take advantage of opportunities as much as possible, using an aggressive strategy to gain new market share. The strategies are presented in the Table 4 sWOT Matrix.

Table 4: SWOT Matrix

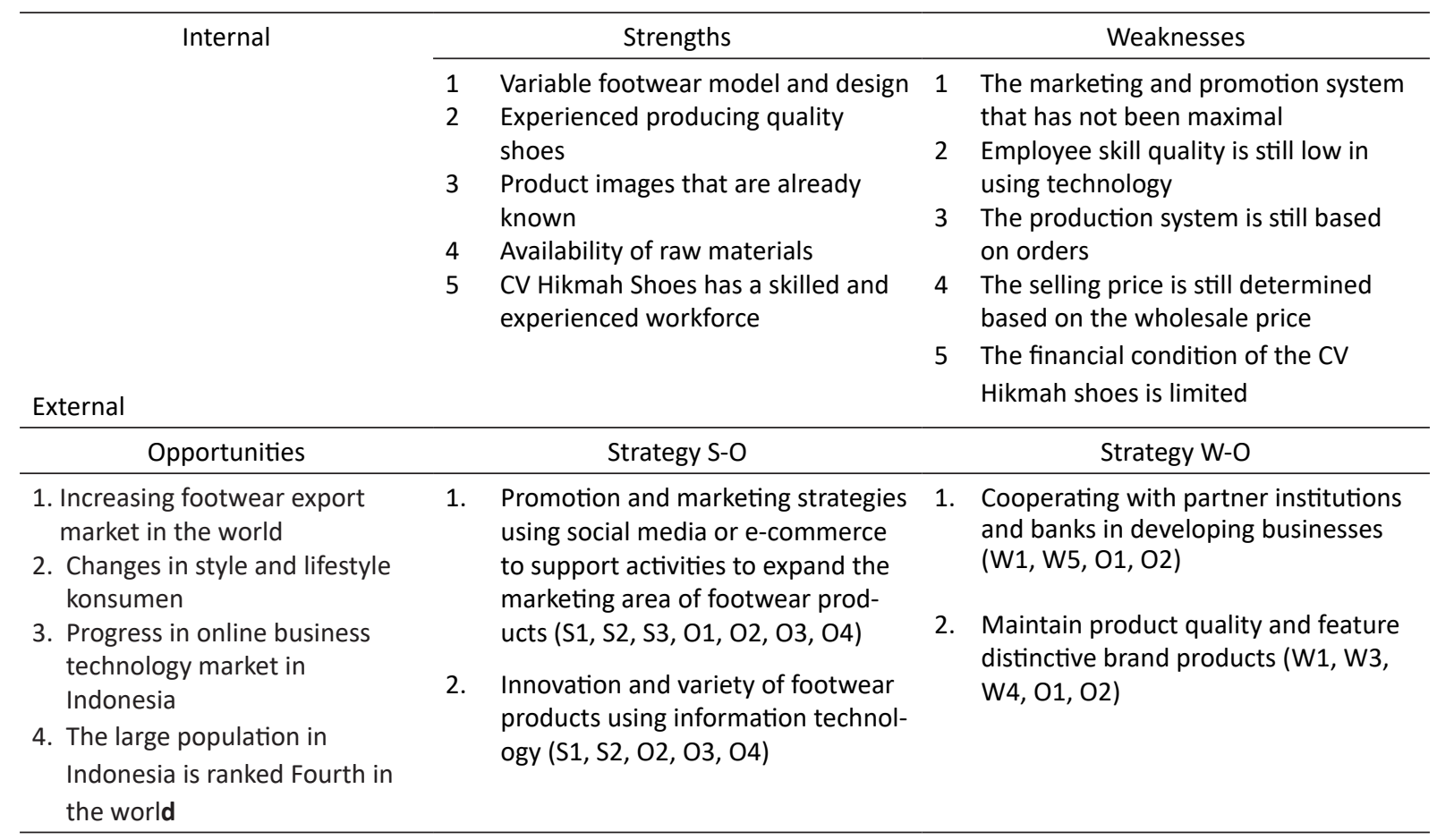




\begin{tabular}{|c|c|c|}
\hline Threats & Strategy S-T & Strategy W-T \\
\hline $\begin{array}{l}\text { 1. Increasing imports of similar } \\
\text { footwear products } \\
\text { 2. High level of competition in } \\
\text { footwear production } \\
\text { 3. Fluctuations in raw material } \\
\text { prices } \\
\text { 4. Unstable economic conditions } \\
\text { Indonesia and world } \\
\text { 5. Government policies are } \\
\text { less supportive footwear } \\
\text { production }\end{array}$ & $\begin{array}{l}\text { 1. Increase productivity capacity to } \\
\text { increase the quantity of footwear } \\
\text { production }(\mathrm{S} 1, \mathrm{~S} 3, \mathrm{~S} 4, \mathrm{~S} 5, \mathrm{~T} 1, \mathrm{~T} 2)\end{array}$ & $\begin{array}{l}\text { 1. Collaboration with the government } \\
\text { regarding HR training, licensing, and } \\
\text { pathways for marketing processes } \\
\text { outside the region (W1, W2, T1, T3, } \\
\mathrm{T} 4, \mathrm{~T} 5)\end{array}$ \\
\hline
\end{tabular}

\section{Stages of Strategy Decision Formation in CV Hikma Shoes}

Making a decision on strategy priorities that are run by the company is the final stage of strategy formulation. The method used in the priority assessment is based on the attractiveness of alternative strategies, so that it can affect the company's internal and external environment. The results of the SWOT matrix analysis produced four alternatives, the SO strategy, the ST strategy, the WO strategy, and the WT strategy. The strategy will be entered into the QSPM matrix which will be estimated by weight and Attractive Score (AS) [15]. SWOT Analysis and Quantitative Strategic Planning
Matrix (QSPM) are advanced analyses commonly used in determining managerial strategies [16, 17].

Strategic priority assessment is done by using the QSPM matrix method by multiplying the weights in the IFE and EFE matrices, multiplying them by the attractive score to produce the Total Attractive Score (TAS). The total number of TAS of each of these strategies determines the priority of the strategy, Determination of Attractive Score (AS) on QSPM and Processing of Total Attractive Score (TAS) QSPM. The results of the Quantitative Strategic Planning Matrix (QSPM) for CV Hikmah Shoes assessment can be seen in Table 5.

Table 5: Alternative strategy

\begin{tabular}{clr}
\hline NO & & Alternative strategy \\
\hline 1 & $\begin{array}{l}\text { Promotion and marketing strategies using social media or e-commerce to support policies to expand } \\
\text { the marketing area of footwear products Maintain product quality and highlight the distinctive brand }\end{array}$ & 6,34 \\
& characteristics of the product. & 6,24 \\
2 & Cooperate with partners, banking institutions and communities in developing businesses & 6,18 \\
3 & Innovation and variety of footwear products by utilizing information technology & 5,96 \\
4 & Cooperate with the government regarding HR training, tax incentives, and pathways for marketing processes & \\
& outside the region & 5,87 \\
5 & Increasing labour productivity to increase the quantity of footwear production. & 5,67 \\
6 & &
\end{tabular}

Based on the results of the QSPM assessment, the order of the highest to lowest TAS (total Attractiveness Score) is obtained. This sequence can be generated by priority strategies that can be implemented at CV Hikmah shoes.

\section{Managerial Implications}

Managerial implications are the company's activities in developing the company's business development strategies that are tailored to the current conditions and capabilities of the company [18]. Based on the results of research on CV Hikmah Shoes, the steps and strategies carried out by making these repairs are carried out as part of the company's sustainability efforts and in an effort to increase the company's revenue. Adjustments from time to time and evaluation of the development of business 
models is very important in implementing a successful business [19].

The implement a prototype business that can be used as a technical description of the strategy obtained from the results of QSPM to support the main business conducted by policies of CV Hikmah Shoes. The company is encouraged to move forward in the business of market penetration in an effort to increase revenue streams. Market penetration will help companies to be independent from reseller dependence. Steps and efforts to do this by using an online business strategy that is an alternative strategy for the company. The strategy based on the results of the QSPM is at the highest value and is in accordance with the results of the IE on quadrant 1 matrix which focuses on market penetration efforts in marketing the product. Online business strategies can also help companies avoid collision marketing with permanent resellers of companies in conventional markets [20].

Another strategy that can be applied by the company is maintaining product quality and highlighting the characteristics of products with its own brand. Companies in marketing can try to create their own brand that represents the identity of CV Hikmah Shoes. Companies can form their own divisions that will carry out promotional programs and market penetration so that existing organizational structures are not disrupted by new programs and strategies that the company will run.

The results of the preparation of the company's business development strategy are logical decisions and consequences that must be prepared by CV Hikmah Shoes in implementing the strategies that have been produced from developing a business improvement but the decision is left entirely to the internal management decisions of CV Hikmah Shoes to be able to measure the company's ability and resource allocation in implementing business development strategies.

\section{CONCLUSION}

The results of calculations on internal and external factors indicate that the current position of CV Hikmah Shoes is in quadrant I which supports aggressive growth policies (Growth oriented strategy). It is very possible to continue to expand, increase growth and achieve maximum progress with a value of $(1.04 ; 0.61)$.

SWOT analysis that produces six alternative strategies with priority strategies with QSPM is a promotion and marketing strategy using social media or e-commerce to support the policy of expanding the area of marketing of footwear products with 6.34 in overcoming the problem of decreasing income and in achieving the desired income target.

\section{REFERENCES}

1. Central Bureau of Statistics, Export foreign trade statistics bulletin according to commodity groups and countries, November 2017, Publication, https://www.bps.go.id.

2. Hubeis, M., Towards Professional Small Industries in the Era of Globalization through Industrial Management Empowerment, Scientific Oration for Permanent Professors of Science, Industrial Management, Faculty of Industrial Technology, Bogor Agricultural University, 2011.

3. Indonesia-Investments, Growth of Indonesia's Export Shoe to Persist in 2016, Today's News, 2016, retrieved from https://www.indonesiainvestments.com/news/todays-headlines/ growth-of-indonesia-s-shoe-export-topersist-in-2016/item6336.

4. Ministry of Trade, The development of imports of non-oil and gas (commodities) periods: 2014-2019. Press conference, 2019, http:// www.kemendag.go.id/id/economic-profile/ indonesia-export-import/growth-of-non-oil- 
and-gas-import-commodity.

5. Ministry of Industry and Trade, Number four labor absorber manufacturing, Industry News, 2017, retrieved from http://www. kemenperin.go.id/artikel/9537/ManufakturAbsorbers-Power-Work-NumberFour.

6. Tehseen, S., Sajilan, S., The impact of innovative practices on business growth under the moderating impact of culture - a conceptual model, Review of Integrative Business and Economics Research, 2016, 5, 2, 28-46.

7. Giesen, E., Riddleberger, E., Christner, R., Bell, R., When and how to innovate your business model, Journal of Strategy and Leadership, 2010, 38, 4, 17-26, https://doi. org/10.1108/10878571011059700.

8. Amit, R., Zott, C., Business model innovation: creating value in times of change, IESE Business School Working Paper No. 870, 2010, IESE Business School, University of Navarra, Pamplona, https://doi.org/10.2139/ ssrn.1701660.

9. Wheelen, T.L., Hunger, D.J., Strategic Management and Business Policy Achieving Sustainability, Twelfth Edition, Pearson, 2010.

10. Pearce, J.A., Robinson, R., Strategic Management - Formulation, Implementation and Control, Jakarta: Salemba Empat, 2013.

11. Barney, J.B., Hesterly, W.S., Strategic Management and Competitive Advantage Concepts and Cases, New Jersey (US): Pearson, 2010.

12. David, F.R., Strategic Management: A Competitive Advantage Approach, A. Dedy, Editor, Jakarta (ID): Salemba Empat, translation from: Strategic Management. A Competitive Advantage Approach, Concepts and Case, 15th ed., 2016.

13. Rangkuti, F., Techniques for Dissecting Business Cases SWOT Analysis, Twenty Two
Edition, Twenty-second Printing, PT Gramedia Pustaka Utama, Jakarta, 2016.

14. Sherafat, A., Yavari, K., Mohammad, S., Davoodi, S., Bozorgzadeh, N., The application of strategic position \& action matrix evaluation in organizational goals and strategies development, J Appl Sci Res, 2013, 9, 4, 2666-2673.

15. Abbasi, F., Esparcia, J., Saadi, A.H., From analysis to formulation of strategies for farm advisory services (case study: Valencia - Spain). An application through swot and QSPM matrix, Europe Countrys, 2019, 11, 1, 43-73, https://doi.org/10.2478/euco-20190004.

16. Rezazadeh, S., Jahani, A., Makhdoum, M., Meigooni, H.G., Evaluation of the Strategic Factors of the Management of Protected Areas Using SWOT Analysis - Case Study: Bashgol Protected Area-Qazvin Province, Open J Ecol, 2017, 7, 55-68, https://doi. org/10.4236/oje.2017.71005.

17. Zulkarnain, A., Wahyuningtias, D., Putranto, T.S., Analysis of IFE, EFE and QSPM matrix on business development strategy, IOP Conf. Series: Earth and Environmental Science, 2018, 126, IOP Publishing, https://doi. org/10.1088/1755-1315/126/1/012062.

18. Boons, F., Freund, F.L., Business models for sustainable innovation: state-of-the-art and steps toward a research agenda, J Clean Prod, 2013, 45, 9-19, https://doi.org/10.1016/j. jclepro.2012.07.007.

19. Osterwalder, A., Pigneur, Y., Business Model Generation. Indonesian edition (language translation by Natalia Ruth Sihandrini), Jakarta: Gramedia, 2012.

20. Hartatik, H., Baroto, T., Business development strategy with the business model canvas method, Journal of Industrial 
Engineering, 2017, 18, 02, 113-120, https:// doi.org/10.22219/JTIUMM.Vol18.No2.113120.
(C) 2019 by the author(s). Published by INCDTP-ICPI, Bucharest, RO. This is an open access article distributed under the terms and conditions of the Creative Commons Attribution license (http://creativecommons.org/licenses/ by/4.0/). 